\title{
Corporate Social Responsibility Disclosure and Firm Performance of Malaysian Public Listed Firms
}

\author{
Mohd Waliuddin Mohd Razali ${ }^{1}$, Winnie Hii Sin $\operatorname{Sin}^{1}$, Janifer Anak Lunyai ${ }^{1}$, Josephine Yau Tan Hwang ${ }^{1}$, Irma \\ Yazreen Md Yusoff ${ }^{1}$ \\ ${ }^{1}$ Faculty Economic and Business, Universiti Malaysia Sarawak, 94300 Kota Samarahan, Sarawak, Malaysia \\ Correspondence: Mohd Waliuddin Mohd Razali, Faculty Economic and Business, Universiti Malaysia Sarawak, \\ 94300 Kota Samarahan, Sarawak, Malaysia.
}

Received: July 16, 2018

doi:10.5539/ibr.v11n9p86
Accepted: August 15, $2018 \quad$ Online Published: August 27, 2018

URL: https://doi.org/10.5539/ibr.v11n9p86

\begin{abstract}
Corporate Social Responsibility (CSR) disclosure has become a rising concern for the public listed firms worldwide due to its ability to enhance firm's market performance and financial performance. The main objective of this study is to investigate the relationship between CSR disclosure and firm performance of Bursa Malaysia's listed companies based on their market value added (MVA), return on equity (ROE) and return on assets (ROA). 324 samples of public listed companies' annual report for the period of 2014 to 2016 were obtained from Bursa Malaysia and examined. The extent of their CSR disclosure were measured and analyzed. After accounting for control variables such as firm size, firm age, firm leverage and firm liquidity, the result shows that there is a positive significant relationship between CSR disclosure and firm performance in terms of ROA and ROE. This reveals that high level of CSR disclosure helps firms to achieve optimum performance through increased competitiveness, improved firm's image amongst society, and creates new opportunities in the marketplace. The findings also showed mix results among the control variables towards firm performance. For future research, this paper recommends to extend the study by using different CSR disclosure measurement, different firm performance measurement such as return on investments (ROI) and Tobin's Q and different samples.
\end{abstract}

Keywords: corporate social responsibility disclosure, firm performance, market value added

\section{Introduction}

For many years, there has been a significant growth in the awareness and practices of Corporate Social Responsibility (CSR) disclosure worldwide. CSR disclosure has been a rising concern for the public listed companies as Malaysia is one of the emerging capital markets. On $14^{\text {th }}$ December 2006, Bursa Malaysia requires all listed companies to report their CSR actions in their annual report (Bursa Malaysia Securities Berhad, 2015). Bursa Malaysia has prepared a CSR framework in 2006 that acts as a guideline for listed companies to report their CSR activities and practices. Although the practice of CSR in Malaysia is completely voluntary and not mandatory, the disclosure of CSR activities is known to provide better transparency. As a result many companies in Malaysia are actively engaging themselves with CSR activities not only to meet the requirement, but also to gain corporate image and competitive advantage. For example, DiGi Telecommunications Sdn. Bhd. as one of the mobile communication firms in Malaysia has well practice CSR disclosure. DiGi had been awarded the "Best overall CSR Programme" in Prime Minister's CSR Awards in 2007 for its efforts and contributions to the society through CSR activities (Wahari, 2007).

The inclusion of CSR activities in annual report is believed to encourage more investors to invest in the firms due to the notion of responsible business conduct has the potential of influencing customers' purchasing behavior which leads to increase in sales of products and customers' loyalty to the brand and hence enable the firms to survive and have better firms' performance in the competitive market. Although all listed companies in Malaysia has disclosed their CSR activities and practices in the annual report, a generic conclusion can be made that these organizations are only focused on certain aspects of CSR especially those that provides them with the highest visibility such as philanthropy and public relation part of CSR that concerns the community and society. Thus, it is crucial to discover the relationship between CSR disclosure and firm performance in term of market and accounting performance to encourage more firms in Malaysia to practice CSR disclosure. It is because the efforts 
toward better CSR practices is vital to create superior development of economy and capital market in Malaysia.

Most of the abroad researchers claimed that CSR has a positive impact on firms' performance. Accounting-based financial indicators like return on equity (ROE) and return on assets (ROA) are widely used to evaluate the firms' performance. In Malaysia, Yusoff and Adamu (2016) discovered that the relationship between CSR disclosure and financial performance in term of ROE and ROA were mostly positive. The stakeholders have more confidence toward the firms that well practicing CSR disclosure would increase when the firms were concerned about the issues in society. Therefore, stakeholders will fully support any ethical actions of the firms to improve firms' performance. This implies that firms' performance can be enhanced by practicing good CSR activities.

On the other hand, market-based financial indicator like market value added (MVA) is less used in earlier studies. The MVA acts as an indicator of how well a firm is able to create returns to investors as well as act as a signal whether the firm has strong leadership and sound governance. CSR disclosure and MVA were found to have mixed relationship. Fooladi and Kolaie (2015) claimed that CSR disclosure had positive impact on MVA. CSR activities could increase the stock price of firms because investors were more confidence with the firms. Meanwhile, it was argued by Dewi, Sudarma, Djumahir, and Ganis (2014) that there was no connection between CSR disclosure and MVA. It was claimed that MVA is derived from other aspects, especially aspects related to return of equity. This indicated that MVA was not totally influenced by company's CSR activities, but also affected by yield of shareholders' capital. Thus, the influence of CSR on improving MVA was small.

There are numerous literatures that explained the effect of CSR disclosure towards firms' performance in Western and European countries, but no works have been done in Malaysia in term of market value added. This causes the extent of the CSR disclosure affecting firms' performance of listed companies in Bursa Malaysia to be less noticeable. Thus, this study is an initiative to further examine the extent of CSR disclosure relationship with firms' performance in term of MVA, ROE and ROA as prior results were inconsistent. This study is designed to fill the gap for earlier studies and offered enhanced evidences in this field.

\section{Literature Review}

Stakeholder theory has been extensively used by empirical researchers to describe the link between CSR disclosure and firm performance. Based on stakeholder theory, CSR activities had effects on revenues and costs. CSR activities could create extra revenue directly or indirectly. Purchasing behavior of customers had direct effect on a company's revenues. With rising consciousness of social and environmental concerns, customers were demanding with CSR related products and remaining loyal to the brands (Servaes \& Tamayo, 2013). Consumer-oriented CSR activities also include intangible elements such as reputation for quality and trustworthiness, which could create product differentiations and generate more revenues (Lev, Petrovits, \& Radhakrishnan, 2010).

The positive relationship between CSR disclosure and firm performance had stayed strong among most of the prior empirical studies. Most of the abroad researchers claimed that the CSR disclosure and financial performance indicators like return on assets (ROA) and return on equity (ROE) had positive relationship. Researchers like Mittal, Sinha and Singh (2008), Fooladi and Kolaie (2015), Mujahid and Abdullah (2014), Kabir and Hanh (2017), Uadiale and Fagbemi (2012), Kanwal, Khanam, Nasreen, and Hameed (2013), Yusoff and Adamu (2016), and Dkhili and Ansi (2012) found the existence of positive effect of CSR on firm performance. A study by Mittal, Sinha and Singh (2008) stated that there was a slight proof that firms with code of ethics had produced additional market value added (MVA) than those without codes. A firm with code of ethics would create significantly more MVA than a firm without the code. These firms had more desirable reputation and image in the marketplace. Then, the desirable reputation and image of firm increased the investors' confidence and thus increased the MVA of firm. Besides, Fooladi and Kolaie (2015) examined that the state of CSR disclosure and MVA of listed companies had a relationship. The state of CSR disclosure could affect the operating performance of the firms by increasing the interest of investors to invest in the firm. This is because CSR actions have increased the firm's stock price which led to a better firm performance.

In addition, CSR has a positive association with return on equity (ROE), return on assets (ROA), earnings per share and price of stock (Mujahid and Abdullah, 2014). This research compared the financial performance and shareholders wealth of CSR firms with non-CSR firms. It was found that CSR concept helped the firms to achieve optimum financial performance in the competitive surroundings by increasing the competitiveness of firms. Other than that, firms that actively involved in CSR activities were found to experience higher financial performance than other firms. Kabir and Hanh (2017) explained that CSR activities helped to enhance the reputation of firms in the eyes of public. Besides, Vietnamese firms that actively involved in CSR activities were also found to experience higher financial performance than other firms. It was because involvement of firms in 
CSR activities could increase the intention of investors to play parts in Vietnamese firms and increase the loyalty of customers towards the brands. The previous findings by Uadiale and Fagbemi (2012) revealed that earnings of organization increased when the firm increased CSR activities. Firm's spending on CSR activities was found to improve the ROE and ROA of firm. CSR activities could create new opportunities in the marketplace and improve image of firm in the society. Kanwal, Khanam, Nasreen, and Hameed (2013) also stipulated that CSR associated with ROA and ROE of the firm positively. Kanwal et al. (2013) added that Pakistani firms' spent on employees' wellbeing to keep existing employees and invited potential employees by building high confidence investors and employees toward the firms. As a result, firms' expenditure on CSR helped the firms to have a long-term supportable development and boosted financial performance of firms.

Also, research by Dkhili and Ansi (2012) debated that CSR and ROE is positive related. The positive relationship between CSR and ROE was due to the presence of stakeholders would improve performance in term of economic. In other words, a company with stakeholders that have more favorable behavior than competitors would have a greater level of financial performance. In Malaysia, Yusoff and Adamu (2016) viewed that positive relationship existed between CSR with ROE and ROA. The comprehensive financial managing could be effectively achieved through proper CSR exercises. Companies' performance could be improved by enhancing good CSR practice. Yusoff and Adamu (2016) also added that sufficient implementation of workplace activities by firms were associated with firms' financial performance. It was pointed out that workplace activities were connected with human capital, value of portfolios and expenses on operating activities directly.

On the other hands, there were few researchers who claimed that CSR disclosure and MVA, ROA and ROE did not have any relationship, such as Dewi et al. (2014) and Kamatra and Kartikaningdyah (2015). Dewi et al. (2014) pointed out that CSR had no effect on MVA. It was refuted that CSR had very little influence on increasing MVA as MVA was also determined from the economic aspects such as inflation and GDP. Increase in MVA does not produce gain directly and could not increase the social actions of firm. Kamatra and Kartikaningdyah (2015) had expressed the view that CSR had no effect on ROE. CSR did not affect ROE because some of the investors did not care about the CSR activities done by the firms as CSR activities was thought as an imaging.

Based on the above literature review, most of the studies claimed that the CSR disclosure and financial performance has a positive relationship (such as Mittal, Sinha \& Singh, 2008; Fooladi \& Kolaie, 2015; Mujahid \& Abdullah, 2014; Kabir \& Hanh, 2017), hence we hypothesized our study as follow:

$\mathrm{H}_{1}$ : There is relationship between CSR disclosure and firm performances.

\section{Methodology}

\subsection{Sample}

The sample in this study was drawn from a set of public listed firms from different sectors, such as Consumer Products, Construction, Properties and Trading-Service in Bursa Malaysia. The final sample includes 324 firms after the removal firms without complete annual reports. The study periods were three years, which is from year 2014 to 2016. In this research, researchers used secondary resources to collect data of Corporate Social Responsibility (CSR) disclosure from annual reports of firms. The financial data of dependent variables such as market value added (MVA), return on equity (ROE) and return on assets (ROA) and control variables like firm's size, age, leverage and liquidity were collected from DataStream by Thomson Reuters.

\subsection{Corporate Social Responsibility (CSR) Disclosure}

CSR disclosure is an instrument for organizations to include social and environmental concerns voluntarily into their operations and relations with stakeholders, which goes beyond the organization's responsibility in regulation (Kusumadilaga, 2006). To measure the disclosure level of CSR in the annual reports, a content analysis approach was adopted. Bowman (1978) came out with the idea of content analysis is an inquiry process which does not rely on casual reading but on rather explicit counting and coding of particular lines of prose, of word usage and of disclosure. The measurement of disclosure was an unweighted count on the number of words on CSR's themes in the annual report. Usage of word counts method assisted in shielding against irregularities in calculating the quantity of disclosure (Zeghal and Ahmed, 1990). In this study, 4 main themes or areas of CSR recommended by Bursa Malaysia to be examined were Environment, Community, Workplace and Marketplace. The words "Environment", "Community", "Workplace" and "Marketplace" which appeared in the annual reports were scanned and counted by using computer.

\subsection{Market Value Added (MVA)}

MVA is a performance measurement tool that calculates increase in the value of the firm's stock price. Investors 
always use MVA to estimate the efficiency of management team of firm on using its capital to increase shareholders' value. A positive value of MVA indicates that the firm has improved in value. A negative value of MVA indicates that the value of firm is destroyed. Berceanu, Siminica, and Circiumaru (2010) have used ratio of change in market value added of the year to total equity of the year to measure MVA.

The measurement of MVA:

$$
\mathrm{MVA}=\frac{\text { Change in market value added of the year }}{\text { Total equity of the year }}
$$

\subsection{Return on Equity (ROE)}

ROE can test the capability of firm to generate profits from the equity. ROE can show the effectiveness of firm using their capital to generate profits. A high ROE indicates the firms management is running efficiently. Kamatra and Kartikaningdyah (2015) have used net income to total equity to measure ROE.

The measurement of ROE:

$$
\mathrm{ROE}=\frac{\text { Net Income }}{\text { Total Equity }}
$$

\subsection{Return on Assets (ROA)}

ROA is used to examine the ability of firms to effectively use its assets to generate profit. A high ROA indicates that the firm is able to achieve higher earnings from its assets and that the firm's assets are used efficiently to generate profits. Dkhili and Ansi (2012) have used net income over total equity to measure ROA. As for this study, the measurement of ROA is as follows:

$$
\mathrm{ROA}=\frac{\text { Net Income }}{\text { Total Assets }}
$$

\subsection{Regression Model}

The multiple regression analysis was used to measure the relationship between Corporate Social Responsibility (CSR) disclosure and firm performance in term of market value added (MVA), return on equity (ROE) and return on assets (ROA), while control variables like firm age, firm leverage, firm liquidity, and firm size were adopted to test their effect toward firm performance. The multiple regression model allowed greater flexibility as we were able to control the variables that influence the dependent variables explicitly.

Functional form: Firm Performance $=\mathrm{f}(\mathrm{CSRD}$, firm age, firm leverage, firm liquidity, firm size $)$

Full model:

$$
\mathrm{FP}_{\mathrm{i}, \mathrm{t}}=\alpha_{\mathrm{i}, \mathrm{t}}+\beta_{1} \mathrm{CSRD}_{\mathrm{i}, \mathrm{t}}+\beta_{2} \mathrm{AGE}_{\mathrm{i}, \mathrm{t}}+\beta_{3} \mathrm{LEV}_{\mathrm{i}, \mathrm{t}}+\beta_{4} \mathrm{LIQ}_{\mathrm{i}, \mathrm{t}}+\beta_{5} \mathrm{LSIZE}_{\mathrm{i}, \mathrm{t}}+\varepsilon_{\mathrm{i}, \mathrm{t}}
$$

Where:-

Dependent variables

FP = firm performance is expressed in terms of:

MVA = Market value added of firm

ROE = Return on equity of firm

ROA $=$ Return on assets of firm 
CSRD = Corporate Social Responsibility disclosure

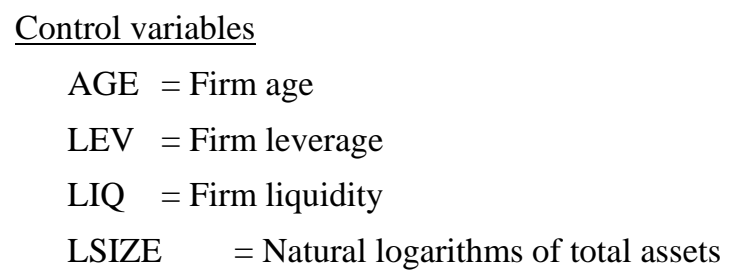

\section{Results and Discussion}

\subsection{Descriptive Statistics}

Table 1 reveals that the mean of market value added (MVA) for the sample firms is 0.0426 times and varies from -2.9878 times (minimum) to 5.2713 times (maximum). The gap between minimum and maximum score of MVA for this study is quite high. The standard deviation is 0.6310 times. MVA is used to measure market-based performance which calculated by measured by ratio of change in market value added of the year to total equity of the year. ROE is the second dependent variable. ROE is measured by ratio of net income to total equity. The average ROE for sample companies is 0.0765 or $7.65 \%$ and ranging from -0.6817 to 0.9507 or ranging from $-68.17 \%$ to $95.07 \%$. The standard deviation is $15.10 \%$. ROA is the third dependent variable. ROA is a measured ratio of net income over total assets. The mean of ROA for the sample firms is $5.12 \%$ with a minimum value of ROA at $-21.67 \%$ and maximum value at $42.55 \%$. The standard deviation of ROA is $7.32 \%$.

Table 1 also displays the descriptive statistics related to mean of the corporate social responsibility (CSR) disclosure. CSR disclosure in the study was measured by using content analysis of word counts. The number of words appeared in annual reports such as "environment", "community", "marketplace", and "workplace" were counted. CSR disclosure in the study has mean of 29.6337 words (range from 3.0000 words to 300.0000 words). The standard deviation lied on 31.0155 words. Table 1 also showed descriptive statistics for control variables in the study. The firm age (AGE) which was calculated by difference between current year to year to incorporation date had an average of 29.1543. The minimum and maximum value for AGE were 3 years and 82 years respectively. The standard deviation of firm age was 14.8648 years. The firm leverage represented by LEV with a mean of 0.2505 times is calculated by ratio of total liabilities to total assets. The range of firm leverage is from the lowest number of 0.0004 times to the highest number of 0.7981 times with standard deviation of 0.1689 times. The firm liquidity represented by LIQ with a mean of 2.7821 times was calculated by ratio of total assets to total liabilities. The range of firm liquidity is from minimum value of 0.1206 times to the maximum value of 45.8595 times with standard deviation of 3.4604 times. Furthermore, firm size represented total assets before natural logarithms has the lowest number of RM23.209 million and highest number of RM133000 million. It has a mean of RM3200 million with standard deviation of RM11100 million.

Table 1. Summary of Descriptive Statistics

\begin{tabular}{cccc}
\hline Variable & Mean & Min & Max \\
\hline MVA & 0.0426 & -2.9878 & 5.2713 \\
ROE & 0.0765 & -0.6817 & 0.9507 \\
ROA & 0.0512 & -0.2167 & 0.4255 \\
CSR & 29.6337 & 3.0000 & 300.0000 \\
AGE & 29.1543 & 3.0000 & 82.0000 \\
LEV & 0.2505 & 0.0004 & 0.7981 \\
LIQ & 2.7821 & 0.1206 & 45.8595 \\
TA (RM 'million) & 3200 & 23.2090 & 133000 \\
\hline
\end{tabular}

4.2 Pearson's Correlation Coefficient Test

Table 2 shows that MVA has a positive correlation with ROA and ROE at 1\% significant level. MVA also has a negative correlation with CSR at 5\% and a negative correlation with LSIZE at 1\% significant level. ROA is second measurement of performance has positive correlation with ROE and LIQ at significant level of 0.01 . ROE is the third dependent variable positively correlated with CSR and LSIZE at 1\%. CSR as independent variable has positive relationship with LEV at $1 \%$ significant level. Meanwhile, for control variables, LEV has positive correlation with LSIZE and negative correlation with LIQ at 1\%. LIQ has negative correlation with LSIZE at $1 \%$ significant level. Correlation does not exist between AGE and LIQ and LSIZE. 
Table 2. Pearson's correlation

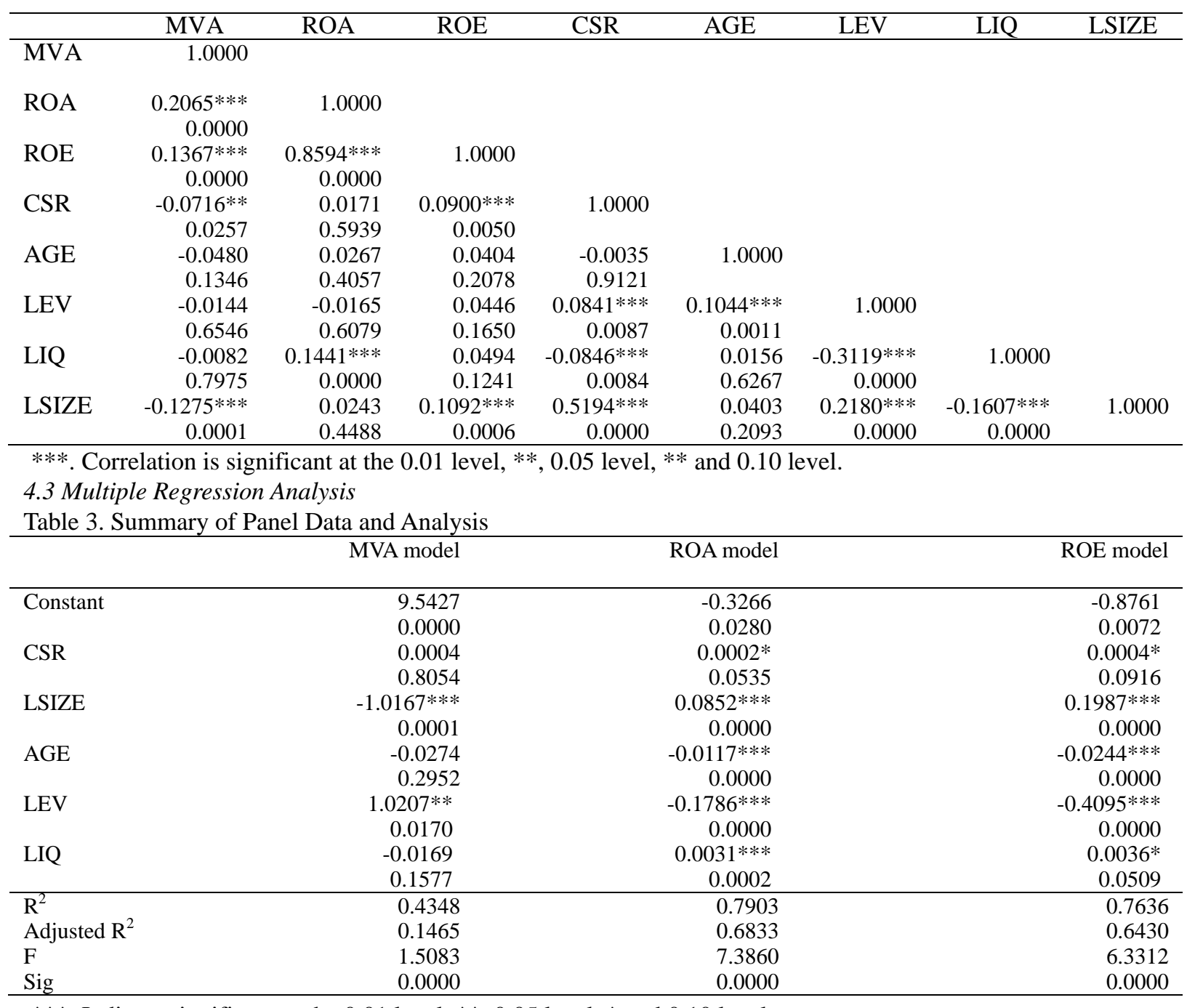

***. Indicate significant at the 0.01 level, **, 0.05 level, * and 0.10 level

Table 3 presents panel data results of MVA (Model 1), ROA (Model 2) and ROE (Model 3).

$$
\mathrm{FP}_{\mathrm{it}} \quad=\alpha+\beta_{1} \mathrm{CSR}_{\mathrm{it}}+\beta_{2} \mathrm{LSIZE}_{\mathrm{it}}+\beta_{3} \mathrm{AGE}_{\mathrm{it}}+\beta_{4} \mathrm{LEV}_{\mathrm{it}}+\beta_{5} \mathrm{LIQ}_{\mathrm{it}}+\epsilon_{\mathrm{it}}
$$

In order to see the relationship between Corporate Social Responsibility (CSR) disclosure and these variables, equations were re-estimated by substituting the dependent variable, Market Value Added (MVA) with Return on Assets (ROA) and Return on Equity (ROE). Table 4.5 summarized the results of the Panel data. Accordingly, equation (1) includes a wider set of dependent variables, like MVA, ROA and ROE represented Model 1, 2, and 3 respectively as different measurements of firm performance.

CSR disclosure was expected to have positive relationship with firm performance in term of MVA, ROE and ROA. The results summarized in Table 3 showed that coefficient value of CSR was 0.0004, 0.0004, and 0.0002 respectively. Based on Model 2 and Model 3, there was a positive significant relationship between CSR and firm performance in term of ROA and ROE with p-value of 0.0535 and 0.0916 respectively. The p-value was less than the level of significance at 0.10 . The higher the disclosure level of CSR, the better the firms' performance. Firms' investment on CSR helped the firms to have long-term supportable development and boosted financial performance of firms. The results were consistent with Mujahid and Abdullah (2014) who concluded that CSR has a positive association with ROA and ROE. It was claimed that CSR concept helped the firms to achieve optimum financial performance in the competitive surroundings by increasing the competitiveness of firms. Firm's spending on CSR activities was found to improve the ROE and ROA of a firm. In addition, CSR activities could create new opportunities in the marketplace and improve image of firm in the society (Uadiale and Fagbemi, 2012). The results of Model 2 and Model 3 had strengthened that CSR has a significant positive 
relationship with firm performance in term of ROA and ROE. However, the findings in Model 1 indicated that MVA is positively insignificant to CSR. The overall outcome was consistent with the study made by Dewi et al. (2014), where there is a positive significant relationship between CSR with ROA and ROE, while positive insignificant relationship between CSR and MVA. Dewi et al. (2014) had enlightened that CSR indexes had supported firms for image building, reputation maintenance and legitimacy of investors to increase capacity of firms which could influence the competitiveness of firms. CSR index is also able to reflect the disclosure level of firms' CSR activities. The high disclosure level of CSR provided trust and increased the desire of investors to play their roles in firms. When more capitals were obtained by the firms, more investments could be done by the firms, and hence the higher the ROE. As a result, CSR is able to provide good financial performance in the form of good ROA and ROE. However, it was refuted by Dewi et al. (2014) that CSR had no effects on increasing MVA. MVA was used to measure effect of managerial performance and influenced by many other economic aspects such as inflation and gross domestic product (GDP). Therefore, increase in CSR activities did not have effect on MVA and this had led to insignificant relationship between CSR and MVA.

Based on Model 2 and Model 3 in Table 4.5, there is positive significant relationship between firm size with ROA and ROE. The p-value of ROA and ROE were 0.0000 , which were less than the level of significance at 0.01. The bigger the firm's size, the better the firms' performance in term of ROA and ROE. This outcome is consistent with Kabir and Thai (2017), Babalola (2013) and Ofuan and Izien (2016). These prior researchers claimed that in emerging countries, larger firms have more resources to have better equipment and professional experts than smaller firms to improve firms' profitability because they had more bargaining power over the market. However, in Model 1, there was negative significant relationship between firms' size and MVA at 1\% significance level. This means that the smaller the firm's size, the better the firms' performance in term of MVA. This result was consistent with Hannan and Freeman (1989) where smaller firms were more creative and innovative where they could easily transform to enhance their values if compared with larger firms.

Next, there is a negative significant relationship between firm age with ROA and ROE. The p-value of ROA and ROE were both 0.0000 , which were less than the level of significance at 0.01 . The younger the firms, the better the firms' performance in term of ROA and ROE. However, in Model 1, there was negative insignificant relationship between firms' age and MVA. The younger the firm's age, the better the firms' performance in term of MVA. The outcome of negative significant relationship between firm age with ROA and ROE was supported by Loderer and Waelchli (2010) where the negative relation of firm age and firm performance could be due to inelasticity and inertia of organizational to identify and involve new innovation in the firm. Contrary, the outcome was inconsistent with prior studies made by Fooladi and Kolaie (2015), Kabir and Thai (2017), and Ofuan and Izien (2016), where these researchers claimed that there was positive significant relationship between firm age and firm performance. These researchers clarified that knowledge of effective production techniques was found to be increase over time and thus improved the performance of the firm which was parallel to the theory of learning by doing. Therefore, old firms would have a better firm performance if compared to younger firms.

Furthermore, firm leverage has a positive relation with ROA and ROE. The p-value of ROA and ROE are 0.0000, which were less than the level of significance at 0.01 . The lower the firm's leverage, the better the firms' performance in term of ROA and ROE. Similar results were found by Fooladi and Kolaie (2015) and Kabir and Thai (2017). Fooladi and Kolaie (2015) observed that growing firms were more conservative when using debt financing in order to maximize their performance. Low level of firm leverage is needed by growing firms as they have low intention of paying high interest. The growing firms also did not totally depend on debt to finance their operating activities as they had more chances to involve in flexible investments. The retained earnings of the firms are also enough for them to finance the firm's activities. However, in Model 1, there is positive significant relationship between firms' leverage and MVA at 5\% significance level with p-value of 0.0170 . The positive significant relationship between firms' leverage and MVA is consistent with past researchers like Modigliani and Miller (1963) and Jensen (1986). The action of firm on using obligation to finance firms' operating activities would increase the value of firms (Modigliani and Miller, 1963). Then, Jensen (1986) had concluded that rises in debt level would raise the firms' market value by keeping low bankruptcy costs. This is because Jensen (1986) found that profitable firms would use more financial leverage to solve the agency problem happened between shareholders and managers which due to inconsistency of interests. To maximize market value of firms, financial leverage was used by shareholders to change the aims of managers on maximizing their own interests only and decrease the agency costs related with equity (Jensen, 1986). Hence, the higher the firm's leverage, the better the firms' performance in term of MVA.

The final variable, which is firm liquidity has a positive significant relationship with ROA and ROE. The p-value 
of ROA is 0.0002 , which is less than the level of significance at 0.01 . Meanwhile, the p-value of ROE was 0.0509 , which is less than the level of significance at 0.10 . The higher the liquidity of the firms, the better the firms' performance in term of ROA and ROE. This result is consistent with prior studies made by Bibi and Amjad (2017) and Janjua, Asghar, Munir, Raza, Akhtar, and Shahzad (2016). This inferred that firms have enough resources to pay off their debts with the available current assets. In other words, firms did not have to sell their profit-generating assets to pay off their obligations. However, in Model 1, there is a negative insignificant relationship between firms' liquidity and MVA. The lower the firm's liquidity, the better the firms' performance in term of MVA. The result is inconsistent with Demirgüneş (2016) where it was claimed that firms with high liquidity could earn more profits because they could make additional profitable investments as they had extra resources in the business.

\section{Conclusion and Implication of the Study}

The result proved that there is positive significant relationship between CSR and firm performance in terms of ROE and ROA which is in line with the stakeholder theory. Therefore, the hypothesis of this study is supported. These findings suggest that high CSR disclosure can enhance firm's corporate image, maintain good reputation, and attracts investors to increase capacity of company, hence, leads to better firm performance. However, not all the predictions made on CSR and firm performance was significant. The outcome shows that CSR has a positively insignificant relationship with MVA.

Firm size as one of the control variables had a positive significant relationship with firm performance in term of ROA and ROE. Besides, firm age is found to have negative significant relationship with firm performance in term of ROA and ROE. Consistent with the hypothesis made, firm leverage is found to have negative significant relationship with firm performance in term of ROA and ROE and positive significant relationship was found between firm leverage and MVA. Lastly, firm liquidity has a positive significant relationship with ROA and ROE.

This study can serve as a guide for investors when making investment choices. The research findings show that CSR disclosure has a positive and significant relationship with firm performance based on their ROA and ROE. This study contributes to a better understanding for investors as to how CSR disclosure helps to create value and increase firm profitability. Besides that, this research aimed to extend and help academics to have better understanding on the factors that determine firm's performance and provide substantial information on CSR in Malaysia context.

On the other hand, this study could also help managers to gain better perception on how to increase firm performance. Manager together with management team must realize that it is crucial to incorporate CSR activities in their business operations due to its ability to create a positive corporate image and portray themselves as a responsible and caring firm towards the societal wellbeing and environmental concerns rather than a mere profit maximizing entity. By disclosing high CSR practice, firm efforts on image building and reputation maintenance can attract more investors that wish to play parts in the firm and hence improve firms' performance.

This study can also act as a point of reference for regulator such as Bursa Malaysia. Bursa Malaysia has to prescribe the contents of CSR activities or practices that the listed issuers should disclose in the annual reports by providing clear guidelines to the listed issuers. This is because most of Malaysian firms have the tendency to focus on community-based and environment-based CSR activities. Bursa Malaysia also needs to provide educational and engaging courses for the listed issuers to familiarize them with moral practices on reporting CSR activities in the annual reports.

\section{Limitation of Study and Recommendation of Future Research}

There are several limitations of this research. Firstly, the CSR disclosure in this study only focuses on the 4 themes or areas of CSR that were outlined by Bursa Malaysia. There are various other themes or areas that can be used to reflect CSR such as human right, ethics and governance, environmental impact, customer health and etc. Sample of this study is also limited to non-financial listed firms. The CSR disclosure may have a different effect towards the performance of financial listed firms and non-listed firms. This study also uses only three performance indicators which are Market Value Added (MVA), Return on Assets (ROA) and Return on Equity (ROE). There are other performance indicators that could be used to measure firm's performance such as Return on investments (ROI) and Tobin's Q and also non-financial indicators that may yield different result. For future research, this paper recommends to extend the study by using different CSR disclosure measurement, different firm performance measurement such as return on investments (ROI) and Tobin's Q and different samples. 


\section{Acknowledgment}

This research is supported by MyRA Grant Scheme [F01/SpMYRA/1681/2018]. We would like to thank Universiti Malaysia Sarawak (UNIMAS) for funding this research.

\section{References}

Babalola, Y. A. (2013). The effect of firm size on firms profitability in Nigeria. Journal of Economics and Sustainable Development, 4(5), 90-94.

Berceanu, D., Siminica, M., \& Circiumaru, D. (2010). The market value added and the return on invested capital for industrial Romanian firms. Finante - provocarile viitorului (Finance - Challenges of the Future), 1(11), 155-161.

Bibi, N., \&Amjad, S. (2017). The relationship between liquidity and firms' profitability: A case study of Karachi stock exchange. Asian Journal of Finance \& Accounting, 9(1), 55-67. https://doi.org/10.5296/ajfa.v9i1.10600

Bowman, E. H. (1978). Strategy, annual reports and alchemy. California Management Review, 20(3), 64-71. https://doi.org/10.2307/41165283

Bursa Malaysia Securities Berhad. (2015). Consultation paper no.1/2015: Proposed amendments to the listing requirements relating to sustainability statement in annual reports and the sustainability reporting guide. Kuala Lumpur: Bursa Malaysia.

Demirgüneş, K. (2016). The effect of liquidity on financial performance: Evidence from Turkish retail industry. International Journal of Economics and Finance, 8(4), 63-79. https://doi.org/10.5539/ijef.v8n4p63

Dewi, D. M., Sudarma, M., Djumahir, \& Ganis, E. S. (2014). CSR effect on market and financial performance. International Journal of Business and Management Invention, 3(1), 56-66. https://doi.org/10.18860/ed.v1i02.2525

Dkhili, H., \& Ansi, H. (2012). The link between corporate social responsibility and financial performance: The case of the Tunisian companies. Journal of Organizational Knowledge Management, 2, 1-11.

Fooladi, N., \& Kolaie, A. Z. Z. (2015). Examining the relationship between disclosure level of corporate social responsibility and the company's operating performance listed in Tehran Stock Exchange by using the economic approach. Indian Journal of Fundamental and Applied Life Sciences, 5(1), 3833-3839.

Hannan, M. T., \& Freeman, J. (1989). Organizational Ecology. Cambridge, Massachusetts: Harvard University Press.

Janjua, A. R., Asghar, A., Munir, U., Raza, A., Akhtar, N. \& Shahzad, K. (2016). Influence of liquidity on profitability of cement sector: Indication from firms listed in Pakistan stock exchange. Business Management Dynamics, 6(5), 1-12.

Jensen, M. C. (1986). The agency cost of free cash flow: corporate finance and takeovers. American Economic Review, 76(2), 323-329.

Kabir, R., \& Hanh, M. T. (2017). Does corporate governance shape the relationship between corporate social responsibility and financial performance. Pacific Accounting Review, 29(2), 227-258. https://doi.org/10.1108/PAR-10-2016-0091

Kamatra, N., \& Kartikaningdyah, E. (2015). Effect corporate social responsibility on financial performance. International Journal of Economics and Financial Issues, 5, 157-164.

Kanwal, M., Khanam, F., Nasreen, S., \& Hameed, S. (2013). Impact of corporate social responsibility on the firm's financial performance. Journal of Business and Management, 14(5), 67-74.

Kusumadilaga, R. (2010). Against the influence of corporate social responsibility corporate values with profitability as moderating variable. Semarang: Faculty of Economics, University of Diponegoro.

Lev, B., Petrovits, C., \& Radhakrishnan, S. (2010). Is doing good good for you? How corporate charitable contributions enhance revenue growth. Strategic Management Journal, 31(2), 182-200.

Loderer, C., \& Waelchli, U. (2010). Firm age and performance, MPRA Paper, University Library of Munich, Germany.

Mittal, R. K., Sinha, N., \& Singh, A. (2008). An analysis of linkage between economic value added and corporate social responsibility. Management Decision, 46(9), 1437-1443. 
https://doi.org/10.1108/00251740810912037

Modigliani, F., \& Miller, M. H., (1963). Corporate income taxes and the cost of capital: a correction. The American Economic Review, 53(3), 433-443.

Mujahid, M., \&Abdullah, A. (2014) Impact of corporate social responsibility on firms financial performance and shareholders wealth. European Journal of Business and Management, 6(31), 181-187.

Ofuan, J. I., \& Izien, F. O. (2016). Firm age, size and profitability dynamics: A test of learning by doing and structural snertia hypotheses. Business and Management Research, 5(1), 29-39.

Servaes, H., \& Tamayo, A. (2013). The impact of corporate social responsibility on firm value: The role of customer awareness. Management Science, 59(5), 1045-1061. https://doi.org/10.1287/mnsc.1120.1630

Uadiale, O. M., \& Fagbemi, T. O. (2012). Corporate social responsibility and financial performance in developing economies: The nigerian experience. Journal of Economics and Sustainable Development, 3(4), 44-54.

Wahari, H. (2007, November 15). PM: Inisiatif masyarakat penyayang hidup subur. Utusan Online. Retrieved from http://ww1.utusan.com.my/utusan/info.asp?y=2007\&dt=1115\&pub=Utusan_Malaysia\&sec=Muka_Hadapa n\&pg=mh_05.htm

Yusoff, W. F. W., \& Adamu, M. S. (2016). The relationship between corporate social responsibility and financial performance: Evidence from Malaysia. International Business Management, 10(4), 345-351.

Zeghal, D., \& Ahmed, S. A. (1990). Comparison of social responsibility information disclosure media used by Canadian firms. Accounting, Auditing \& Accountability Journal, 3(1), 38-53.

https://doi.org/10.1108/09513579010136343

\section{Copyrights}

Copyright for this article is retained by the author(s), with first publication rights granted to the journal.

This is an open-access article distributed under the terms and conditions of the Creative Commons Attribution license (http://creativecommons.org/licenses/by/4.0/). 